\title{
The Impact of Anti-Money Laundering on Investment Funding: Evidence from Jordanian Financial Institutions
}

\author{
Husni Ali Khrawish ${ }^{1}$ \\ ${ }^{1}$ Department of Banking and finance, Faculty of Economics \& Administrative Sciences, Hashemite University, \\ Jordan \\ Correspondence: Husni Ali Khrawish, Department of Banking and finance, Faculty of Economics \& \\ Administrative Sciences, Hashemite University, Jordan. E-mail: h.a.khrawish@gmail.com
}

Received: December 22, 2013

Accepted: January 14, $2014 \quad$ Online Published: February 25, 2014

doi:10.5539/ijef.v6n3p227

URL: http://dx.doi.org/10.5539/ijef.v6n3p227

\begin{abstract}
The main objective of this study is to examine the impact of Anti -money laundering (AML) on investment funding: Evidence from Jordanian financial institutions. Study population consists of the financial sector which includes 72 Banking and financial institutions and a sample study of 50 Jordanian financial institutions is selected in order to achieve the objectives of the Anti-Money Laundering and Counter Terrorism Financing. This study depends on a survey that asks the executive managers certain questions in order to know how anti -money laundering impacts investment funding. Also this study applies a version of the model by using a Multiple Linear Regression Model and single model to testing the hypotheses of this study.

In light of analyzing the data and testing the hypotheses, the following results have been reached: The impact of money laundering (ML) on investment funding is a significant and negative relationship between ML and investments funding (INVF). Also, there is a significant and positive relationship between AML (Systems and regulations, Controlling, Auditing, Training and money transfer) and investment funding (INVF).

To reduce the impact of Money laundering which represents a financial crime that might have negative affect on the stability of the economy, and investment funding, the researcher suggests many solutions regarding the laws and regulations, controlling, auditing, training and transfers.
\end{abstract}

Keywords: anti-money laundering, counter terrorism financing, laws and regulations, controlling, auditing, training and transfer

\section{Introduction}

Money laundering is a financial crime that might negatively impact the stability of the economy, especially on investment funding (Jack Law Group, 2013); money laundering is typically described as the ownership of property obtained through illegal to legitimate sources (Conyers \& Pearman, 2013).

Also, Money laundering is the process of converting dirty money into clean funds by using a high ranking employees in large corporations divert money to personal accounts, tax evasion, prostitution, or drug trafficking. There are many ways to launder money; the best ways to launder money are through the using of financial institutions, businesses and companies that serve as a front for receiving the illicit funds. (https://twitter.com/WorldCompliance/2013).

The statistical of the United Nations Office on Drugs and Crime (UNODC) shows the size of illicit funds which has been established by drug trafficking and organized crimes and to investigate to what extent these funds are laundered. The report estimates that in 2009, criminal proceeds amounted to $3.6 \%$ of global GDP, with $2.7 \%$ (or USD 1.6 trillion) being laundered. Between 2009 and 2010, more than 1,200 new anti -money laundering (AML) installations were implemented by vendors interviewed. The global market is currently at US $\$ 450$ million, and will grow at a compound annual growth rate (CAGR) of 9\% over the next few years, reaching US\$690 million in 2015. Market drivers include rapid growth in the Asia-Pacific, the Middle East, and Africa.

Nearly one-fifth of financial institutions do not formally test and monitor the effectiveness of their AML systems and controls (kpmg.com, Global Anti-Money Laundering Survey, 2011). 
Table 1. The percentage of formally test and monitor of AML systems and controls in financial institution in most of the world

\begin{tabular}{lll}
\hline country & $\mathbf{2 0 0 7}$ & $\mathbf{2 0 1 0}$ \\
\hline Europe countries & $70 \%$ & $85 \%$ \\
North America & $92 \%$ & $93 \%$ \\
Russia & $75 \%$ & $83 \%$ \\
South America & $81 \%$ & $93 \%$ \\
Middle east & $76 \%$ & $79 \%$ \\
\hline
\end{tabular}

Source: (kpmg.com, Global Anti-Money Laundering Survey 2011).

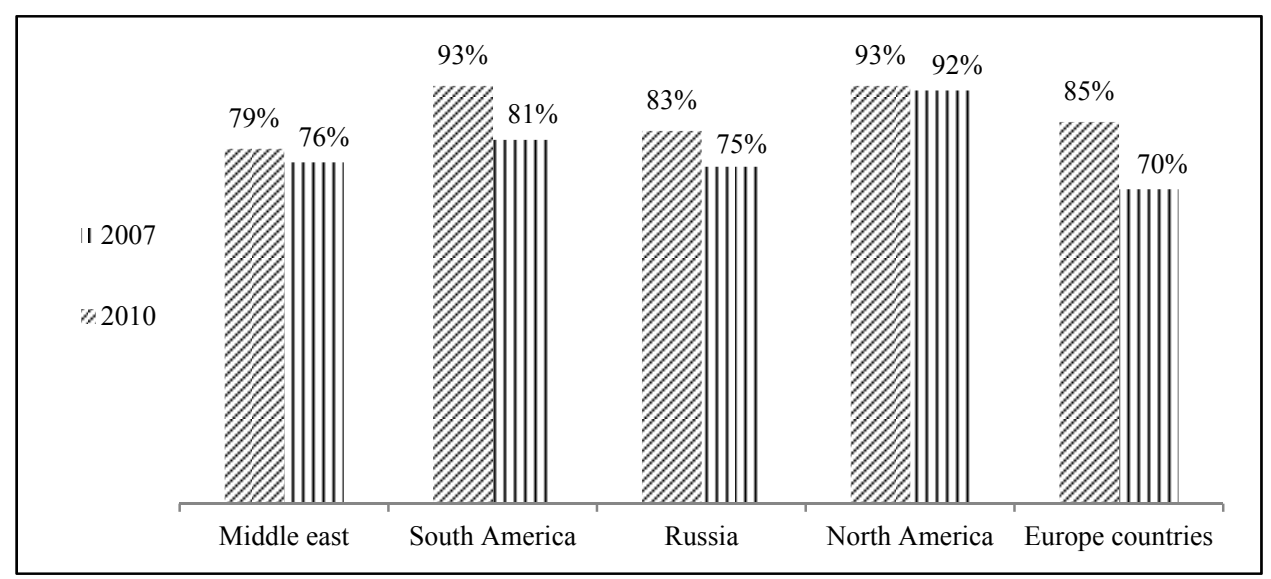

Figure 1. The percentage of formally test and monitor of AML systems and controls in financial institution in the most of the world

Table 1 showes that the financial institutions in North America considered the nations of the world's most stringent anti-money laundering (AML), while the Middle East is one of the world's most lenient in this matter.

Money laundering is estimated in Jordan between 2008-2012 more than one billion dollars, it is amounted to 3\% of GDP, with $2 \%$ being laundered. Between 2008 and 2012.These statistics are approximate. It depends on a survey and interviews that asks the executive managers certain questions in order to know how anti -money laundering impacts investment funding. On the other hand the average direct foreign investment (DFI) represent about 7\% of GDP and the average investment funding (INVF) represent about 4.5\%of GDP between 2008 and 2012. (International Monetary Fund, 2013).

Table 2. The percentage for direct foreign investment (DFI), money laundering (ML) and anti -money laundering (AML) of GDP throw the period 2008-2012

\begin{tabular}{cccc}
\hline \multirow{2}{*}{ Years } & $\begin{array}{c}\% \text { direct foreign investment of real } \\
\text { GDP }\end{array}$ & $\begin{array}{c}\% \text { money laundering of } \\
\text { real GDP }\end{array}$ & $\begin{array}{c}\% \text { anti }- \text { money laundering of } \\
\text { real GDP }\end{array}$ \\
\hline 2008 & $12.87 \%$ & $3.4 \%$ & $2.7 \%$ \\
2009 & $10.13 \%$ & $3.5 \%$ & $2.8 \%$ \\
2010 & $6.25 \%$ & $4.1 \%$ & $3.4 \%$ \\
2011 & $5.09 \%$ & $4.3 \%$ & $3.1 \%$ \\
2012 & $4.49 \%$ & $4.3 \%$ & $3.2 \%$ \\
\hline
\end{tabular}

Source: The statistical of \% direct foreign investment of real GDP is taken from World Bank, 2013and International Monetary Fund, 2013 , but the statistical of $\%$ money laundering of real GDP and $\%$ anti -money laundering of real GDP are depends on a survey and interviews of this study. 


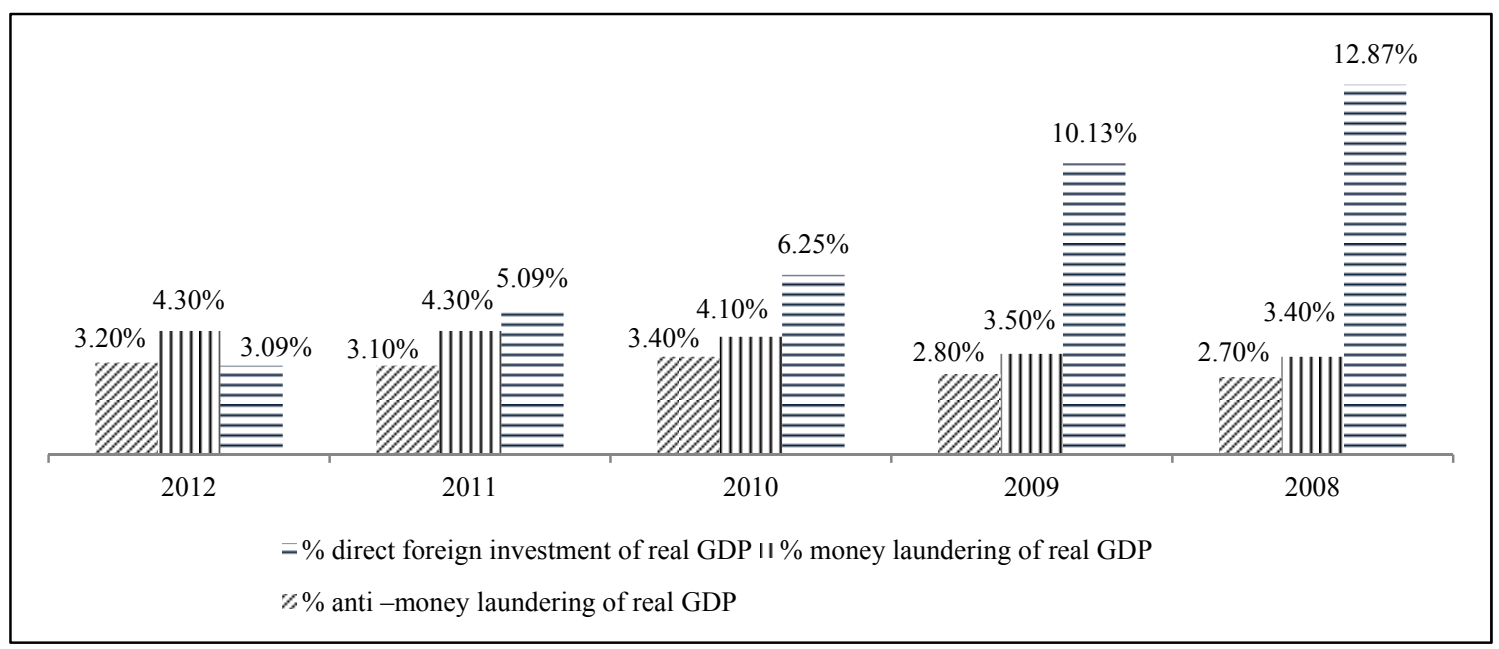

Figure 2. The percentage direct foreign investment (DFI), money laundering and anti-money laundering of GDP throw the period 2008-2012 (Billion USD)

Table 2 showes that DFI\%GDP is decreased from $12.87 \%$ to $4.49 \%$, Also this table showes the percentage money laundering of GDP throw the period 2008-2012 increased from $3.2 \%$ to $4.3 \%$ and anti-money laundering of GDP increased from $2.7 \%$ to $3.2 \%$.

Many researchers believe that DFI \%GDP is decreased and money laundering is increased in the recent year because of the increasing emigration from Arab spring. (World Bank, 2013; Balata \& khababa, 2006).

Financialins titutions in Jordan and other countries like United States and Europe replacing outdated solutions; and smaller financial institutions replacing manual processes with automated solutions (United Nations Office on Drugs and Crime (UNODC) 2009 and 2010).

So, the using of AML is required some solutions to reduce the financial crime. These solutions include:

i. Customer due diligence (CDD);

ii. Suspicious activity monitoring (SAM);

iii. Know your customer (KYC);

iv. Case management and watch-list filtering.

Also, financial institutions are required to consider the Anti-Money Laundering and Counter Terrorism Financing (AML/CTF) obligations when they provide 'designated services' under the regulations:

- Check opening an account;

- Check accepting money on deposit;

- Check when the bank gives the loans;

- Check when the bank issues a debit card;

- Check when the bank issues travelers' checks;

- Check when the bank Send and received instructions on electronic funds transfers.

These items will help protecting the integrity and the reputation of the financial system.

\subsection{Importance of the Study}

The importance of this study is to encourage the funding of investments and it protects from ML by anti- money laundering which includes fighting the: terrorism financing, drug trafficking, weapons trafficking and money that result from bribery, exploitation of public office, commissions and trading on black market.

Also, the importance of anti-money laundering is to find the appropriate solutions which relating to money laundering that include customer due diligence (CDD), suspicious activity monitoring (SAM), know your customer (KYC), case management, and watch-list filter.

Finally this study is considered the first one in Jordan. 


\subsection{Objectives of the Study}

The main objective of this study is to examine the impact of Anti-money laundering (AML) on investment funding (INVF): Evidence from Jordanian financial institutions.

So the main research question is: How Anti-money laundering (AML) effects investment funding?

The answer of this question is by fighting the financial crimes which represents:

- Terrorism Financing;

- drug trafficking;

- weapons trafficking;

- money that result from bribery, exploitation of public office, commissions and trading on black marke;

- the theft of state funds, tax evasion and smuggling good and cash;

- steal of inventions, monuments, and speculator in land and real estate in stock marke;

- espionage activities and borrowing from bank without adequate safeguards, collection of depositor's money and smuggled abroa;

- Counterfeiting money and other banking instrument.

For example: the fighting of financial crimes increased investment funding instead of going to illicit funds which represents terrorism Financing, drug trafficking weapons trafficking and organized crimes------etc. (kpmg.com, Global Anti-Money Laundering Survey, 2011)

Accordingly, the regulations of financial transactions help detecting and preventing money laundering and terrorism financing. Also, it is required Key components of AML solutions include customer due diligence (CDD), suspicious activity monitoring (SAM), know your customer (KYC), case management, and watch-list filtering.

\subsection{Problem of the Study}

The Problem of the study is to answer the following questions:

- Is there an impact of the Money Laundering (ML) on investment funding?

- Is there relationship between the impact of Anti-Money Laundering (AML) (Systems and regulations) and investment funding?

- Is there relationship between the impact of Anti-Money Laundering (AML) (Controlling) and investment funding?

- Is there relationship between the impact of Anti-Money Laundering (AML) (Auditing) and investment funding?

- Is there relationship between the impact of Anti-Money Laundering (AML) (Training) and investment funding?

- Is there relationship between the impact of Anti-Money Laundering (AML) and Money transfer?

\section{Literature Review and Previous Studies}

There are many studies that are concerned with this subject such as:

Aluko (2012) study the effect of money laundering on funding investment. He found that money laundering and financial crimes have a negative effect on economic growth and financial stability.in different countries. So, it is required from these countries working together to reduce the effects negatively which regarding of funding investment, jobs and new technologies. Also, Aluko found a positive relationship between corruption and money laundering in most countries.

Idowu (2012) investigate that money laundering has negative consequences on the funding investments which effect on the revenues of the government, economic growth rate and threatens the political stability and internal security of a nation. Therefore, it needs to check the activities of financial institutions because it plays an important role in financing the investments in different countries.

Ihsan \& Razi (2012), discovered that the money laundering has an effect on national income and it also affects the foreign investment. According to both respondents, there are some anti-money laundering laws that can prevent the money laundering. According to both respondents, the laundered money for the welfare of nation can be re-used. Government can also stop the money laundering through tax saving, efficient banking record system 
and develop awareness in nation by media. So the five elements on which the whole study is consisted are the ways for improving the laws against money laundering and reducing this evil crime.

Ayodegi (2011) found that money laundering effects on economic growth and financial stability. As the financial institutions play an important role in financing the investments it requires them to fight money laundering by check the opening accounts, accepting money on deposit and gives the loans. These informations were made to reduce money laundering, financial crime and terrorist financing.

FATF (2009), showes that the use of the securities industry to launder money is considered an actual threat because it reduced the financing of securities and converting dirty money into clean funds by using of financial institutions. Therefore it is required more traditionally associated with ML/TF, such as financial intuitions, are tightened, the use of the securities industry may become a greater temptation to those seeking to disguise illicit proceeds, or indeed to generate them.

Brigitte et al. (2006) investigate that the economy was affected negatively by money laundering, financial crime and terrorist financing. Therefore, the ability of cash flows between countries has many benefits, if these countries were able to fight money laundering and financial crime and terrorist financing because the fight of money laundering and financial crime and terrorist financing will reduce the effects negatively in regards of funding investment, jobs and new technologies.

Maria et al. (2005), investigate what are the ways which can increase or decrease of cash flows from Switzerland to the USA after the passage and enactment of the Federal Act to prevent the Money Laundering in the financial institutions. Maria et al are finding also after the Money Laundering Act (MLA) during 10 October 1997 and 1 April 1998 a significant increase in the amounts of cash flows out of the country during the period 1998-2000 because it is easier for a company or individual to move their capital between countries.

Bartlett (2002) investigate that the economy is affected negatively by money laundering, because the money laundering (ML) effect on economic growth and works to reduce productivity and transfer of funds to the acts of crime and corruption. Therefore, money laundering will reduce the foreign trade and cash flows in the long term, which requires anty-money laundering (AML) from all States. On the other hand, he also suggested from developing countries establish offshore financial centers (OFCs) as vehicles for economic development and reduce the crime and corruption.

Quirk (1997) discovered that the size of money laundered annually in the financial system is worldwide, in UK and the US officials about $\$ 500$ billion distributed as follow:

$2 \%$ of global GDP and a $10 \%$ increase in crime are associated with a $10 \%$ reduction in currency demand and a $6 \%$ reduction in overall money demand.

Also, Quirk found that there is a positive effect between money laundering and macroeconomic variables, because accumulated balances of laundered assets are a larger than annual cash flows between countries.

Quirk (1996) examined the effect of macroeconomic of money laundering on the stability of the economy, and investment funding. Also he discussed how money laundering can be measured and investigated the econometric on monetary behavior in industrial countries to anti- money laundering (AML). Finally, he found that antimoney laundering (AML) required the controlling of exchange rate, banking supervision, tax evasion, statistical reporting and legislation because all of these factors that impact on economic growth rates and works to protect the negative effects of the economy.

Tanzi (1996) analyzed that there is a positive effect between anti-money laundering (AML) and the activities of the international economy and international financial markets because the globalization of economic activities works to lowest the cost of anti-money laundering (AML). Although the facility with which dirty/money can now be laundered internationally this works to lowest the cost of anti-money laundering (AML). Finally, Tanzi found a positive relationship between globalization and money laundering, as well as some to the economic implications of large-scale money laundering.

\section{Methodology}

\subsection{Data Collection}

The data collection process is an essential part of the research hence it is the way that will be used to collect relevant information about the research objectives in order to answer the research questions. (Swisher, 2011).

For this research, the researcher used a survey for collecting data, and I analyzed it in a quantitative approach. A quantitative approach can be very useful for this research hence it summarizes very complex into a format that tells a story in a way that is very convincing for everyone. (Mark, 2012). 


\subsection{Research Design}

From the theoretical and practical theories and insights formulated and reevaluated in literature review, this study will use a model which depends on a quantitative approach for Measuring the impact of anti-money laundering on investment funding: in Jordanian context.

Moreover, the researcher depends on literature review to compare his results with the results of its studies which depends on a survey and interviews.

This study similar to previous studies which depends on a survey and interviews that asks the executive managers certain questions in order to know how anti-money laundering impacts investment funding and it is different from previous studies because of differences in the economic and social conditions in many countries.

The current Study population included 72 banking and financial institutions and a sample study of 50 Jordanian financial institutions is selected in order to achieve the objectives of the Anti-Money Laundering and Counter Terrorism Financing (AML/CTF Act).

The survey in this study will be asking simple questions with simple answers (yes/no) and will be divided into:

- Impact of the Money Laundering (ML) on investment funding;

- Impact of the Anti - Money Laundering (AML) on investment funding which regarding:

-Systems and regulations;

- Controlling;

- Auditing;

-Training;

- Transfer.

The researcher chooses 4 AML variables because it is the most used in financial institutions to consider the Anti-Money Laundering and Counter Terrorism Financing (AML/CTF) obligations when they provide 'designated like banking and insurance companies.

To examine the impact of Anti-money laundering (AML) on investment funding: Evidence from Jordanian financial institutions, this study applies a version of the model by using a Multiple Linear Regression Model and single models (applying statistical methods (SPSS). This model analyzes the impact of Anti -money laundering (AML) on investment funding by using the following form

$$
\begin{gathered}
I N V F=f(M L) \\
I N V F=f(A M L)
\end{gathered}
$$

Where: INVF = investment funding;

$M L=$ money laundering variable;

$\mathrm{AML}=A$ vector of Anti -money laundering variable;

AML includes (SYRG, CON, AUD, TR and TRE);

Where:

$S Y R G=$ Systems and regulations;

$C O N=$ Controlling;

$A U D=$ Auditing;

$T R=$ Training;

$T R A=$ Transfer.

In order to estimate the INVF function, the following basic linear model of INVF is specified as:

Model (1):

Model (2)

$$
\mathrm{INVF}=a_{o}+a_{1} M L t+e_{t}
$$

$$
\mathrm{INVF}=a_{o}+a_{1} S R_{t}+a_{2} \mathrm{CON}_{t}+a_{3} A U D_{t}+a_{4} T R_{t}+a_{5} T R A_{t}+e_{t}
$$




\subsection{Explanatory Variables}

Independent and dependent variables of the current study have been measured according to the results reached by previous studies and how far data have been available for measurement purposes. Also, this study have been determined according to the survey and interviews that asks the executive managers certain questions in order to know how anti -money laundering impacts investment funding.

\subsection{Hypotheses}

Based on the measurement of the impact of anti-money laundering (AML) on investment funding for institutions, the following hypotheses will be constructed:

H1: There is a significant and negative relationship between ML and investment funding (INVF);

H2: There is a significant and positive relationship between AML (Systems and regulations) and investment funding (INVF);

H3: There is a significant and positive relationship between AML (Controlling) and investment funding (INVF);

H4: There is a significant and positive relationship between AML (Auditing) and investment funding (INVF);

H5: There is a significant and positive relationship between AML (Training) and investment funding (INVF);

H6: There is a significant and positive relationship between AML (transfer) and investment funding (INVF).

\section{Discussion and Analysis}

To examine the hypotheses regarding the impact of Anti -money laundering (AML) on investment funding: Evidence from Jordanian financial institutions, this study applies the models by using a single model and Multiple Linear Regression Model applying statistical methods (SPSS).

\subsection{Testing the First Hypothesis}

H1: There is a significant and negative relationship between ML and investment funding.

Table 3 summarizes the descriptive statistics for the variables.

Table 3. Summarizes the descriptive statistics of the variables ML and investment funding

\begin{tabular}{lcc}
\hline Variable & Mean & Standard D \\
\hline INVF & 4.567 & .829 \\
ML & 2.567 & 0.929 \\
\hline
\end{tabular}

Table 3 appears the mean of investment funding $(I N V F)$ are 4.567 this ratio means that the percentage INVF of real GDP over the period (2008-2012) equal $4.567 \%$ of GDP and the mean of money laundering (ML)represent $2.567 \%$ of GDP over the same period. These ratios are acceptable when we compare it with other ratios in similar countries like Nigeria (Ayodeji \& Mahmood, 2012).

Also, Table 3 appears that standard deviation for INVF equal 0.829, and standard deviation for ML equal 0.929. These ratios are high when we compare it with developing countries like Pakistan (Iqra \& Amir, 2012).

Table 4 shows the results of regression analysis of investment funding (INVF) and money laundering (ML):

Table 4. Regression analysis of investment funding (INVF)

\begin{tabular}{lccc}
\hline Variable & T & Sig(1) & coefficients \\
\hline Constant & .8725 & .007 & 1.875 \\
$\boldsymbol{M L}$ & 4.325 & 0.023 & -1.654 \\
\hline
\end{tabular}

This table shows that there is a significant and negative relationship between ML .and investment funding (INVF) and the (T-Test) for this hypothesis is 4.325 . IT means that Coefficient between ML and INVF is negative, that equal -1.654 degree and this coefficient is significant equal 0.023 at the 0.05 level.

As expected, the first hypothesis (H1) is a negative relationship between INVF and ML. This result is similar to those results that are obtained by (Tanzi, 1996)and (Ihsan \& Razi, 2012).

As well as, this result is similar to that of the first hypothesis (H1). Also, the following table appears the answer of 
question 1 which regarding the impact of money laundering (ML) on investment funding.

Question one: Is there impact of the Money Laundering (ML) on investment funding?

Table 5. Appears the impact of money laundering (ML) on investment funding

\begin{tabular}{lcc}
\hline Answer Options & Response Percent & Response Count \\
\hline Yes & $60.0 \%$ & 30 \\
No & $16.0 \%$ & 8 \\
Sometimes & $6 \%$ & 3 \\
skipped question & $18 \%$ & 9 \\
Total & $100 \%$ & 50 \\
\hline
\end{tabular}

The following figure shows the impact of the Money Laundering (ML) on investment funding

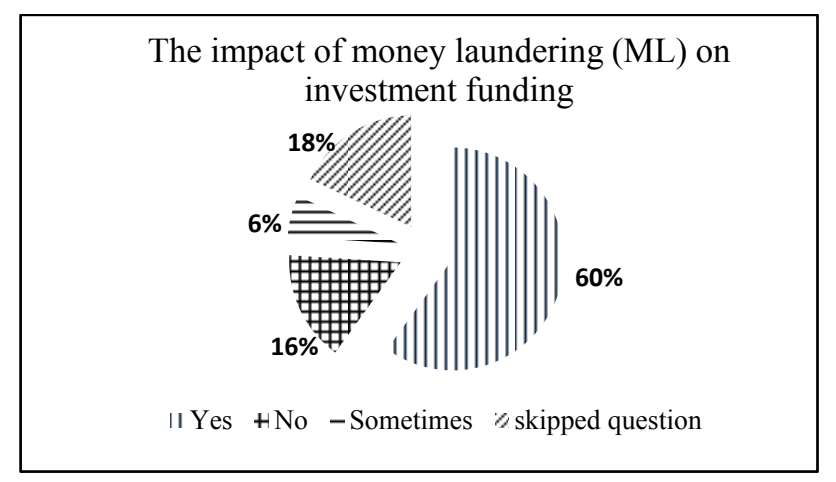

Figure 3. The impact of money laundering (ML) on investment funding

It is clear from table No.5 that the ratio of people who answered that the Money Laundering (ML) effect on investment funding $60 \%$, and the ratio of who answered that the Money Laundering (ML) not effect on investment funding $16 \%$ And the ratio of who answered that the Money Laundering (ML) sometimes effect on investment about $6 \%$, and the last of who skipped question about $18 \%$, the higher this ratio because of the sensitivity study questions.

So, we can notice that the result regarding with the impact of money laundering (ML) on investment funding is a significant relationship between ML and investments funding (INVF).

\subsection{Testing the other Hypothesis}

$\mathrm{H} 2$ : There is a significant and positive relationship between AML (Systems and regulations) and investment funding;

H3: There is a significant and positive relationship between AML (Controlling) and investment funding;

H4: There is a significant and positive relationship between AML (Auditing) and investment funding;

H5: There is a significant and positive relationship between AML (Training) and investment funding;

H6: There is a significant and positive relationship between AML and money transfer.

Table 6. The descriptive statistics of the variables AML and investment funding

\begin{tabular}{lcc}
\hline Variable & mean & Standard D \\
\hline INVF & 4.567 & 0.829 \\
SYRG & .567 & 0.529 \\
CON & .725 & 0.842 \\
$A U D$ & .652 & 0.754 \\
$T R$ & .534 & 0.657 \\
$T R A$ & .245 & 0.425 \\
\hline
\end{tabular}


Table 6 appears that mean of investment funding $(I N V F)$ are 4.567 this ratio means that the percentage $I N V F$ of real GDP over the period (2008-2012) equal $4.567 \%$ of GDP.

And standard deviation of investment funding (INVF) equal 0.829, and the mean of Anti-money laundering (AML) are (0.567 SYRG), (0.725 CON), 0.652 AUD), (0.534 TR) and (0.245 TRA) and standard deviation are(0.529 SYRG), (0.842 CON), (0.754 AUD), (0.657 TR) and (0.425 TRA). These ratios represent that Systems and regulations $(S Y R G)$ fights money laundering 0.567. Controlling (CON) fights money laundering 0.725 , Auditing(AUD) fights money laundering 0.652 , Training $(T R)$ fights money laundering 0.534 and money transfer. (TRA) fights money laundering 0.245 .

These ratios are acceptable when we compare with other ratios in similar countries like Nigeria (Ayodeji \& Mahmood, 2012). Also these ratios are similar in the developed countries like UK and USA (Quirk, 1997).

Table 7 shows also the results of regression analysis of investment funding (INVF) and Anti-money laundering (AML):

Table 7. Regression analysis of investment funding (INVF) and Anti-money laundering (AML)

\begin{tabular}{lccc}
\hline Variable & T & Sig(1) & coefficients \\
\hline Constant & .8725 & .0070 & 1.875 \\
SYRG & 4.325 & 0.023 & 2.354 \\
CON & 3.245 & 0.034 & 2.245 \\
AUD & 3.147 & 0.048 & 3.214 \\
TR & 2.784 & 0.034 & 3.452 \\
TRA & 2.546 & 0.001 & 2.421 \\
\hline
\end{tabular}

Table 7 shows that there is a significant and positive relationship between AML (SYRG 0.023, CON 0.034, AUD $0.048, T R 0.034$ and TRA 0.001) and investment funding (INVF) and the (T-Test) for this hypothesis are (SYRG 4.325, CON 3.245, AUD 3.147, TR 2.784 and TRA 2.546).

As expected, these results are a significant and positive relationship between AML and investment funding $(I N V F)$. These results are similar to those results that are obtained by (Tanzi, 1996) and (Ihsan \& Razi, 2012).

Also, the following table appears the answer of the following questions:

Is there relationship between the impact of Anti-Money Laundering (AML) (Systems and regulations) and investment funding?

Is there relationship between the impact of Anti-Money Laundering (AML) (Controlling) and investment funding?

Is there relationship between the impact of Anti-Money Laundering (AML) (Auditing) and investment funding?

Is there relationship between the impact of Anti-Money Laundering (AML) (Training) and investment funding?

Is there relationship between the impact of Anti-Money Laundering (AML) and Money transfer?

Table 8. Summarizes the descriptive statistics for these variables

\begin{tabular}{cccccc}
\hline AML Answer option & $\begin{array}{c}\text { Systems and } \\
\text { regulations }\end{array}$ & Controlling & Auditing & Training & $\begin{array}{c}\text { Money } \\
\text { transfer }\end{array}$ \\
\hline Yes & $70 \%$ & $65 \%$ & $75 \%$ & $50 \%$ & $63 \%$ \\
No & $7 \%$ & $10 \%$ & $5 \%$ & $15 \%$ & $17 \%$ \\
Some times & $5 \%$ & $7 \%$ & $2 \%$ & $17 \%$ & $2 \%$ \\
Skipped question & $18 \%$ & $18 \%$ & $18 \&$ & $18 \%$ & $18 \%$ \\
Total & $100 \%$ & $100 \%$ & $100 \%$ & $100 \%$ & $100 \%$ \\
\hline
\end{tabular}




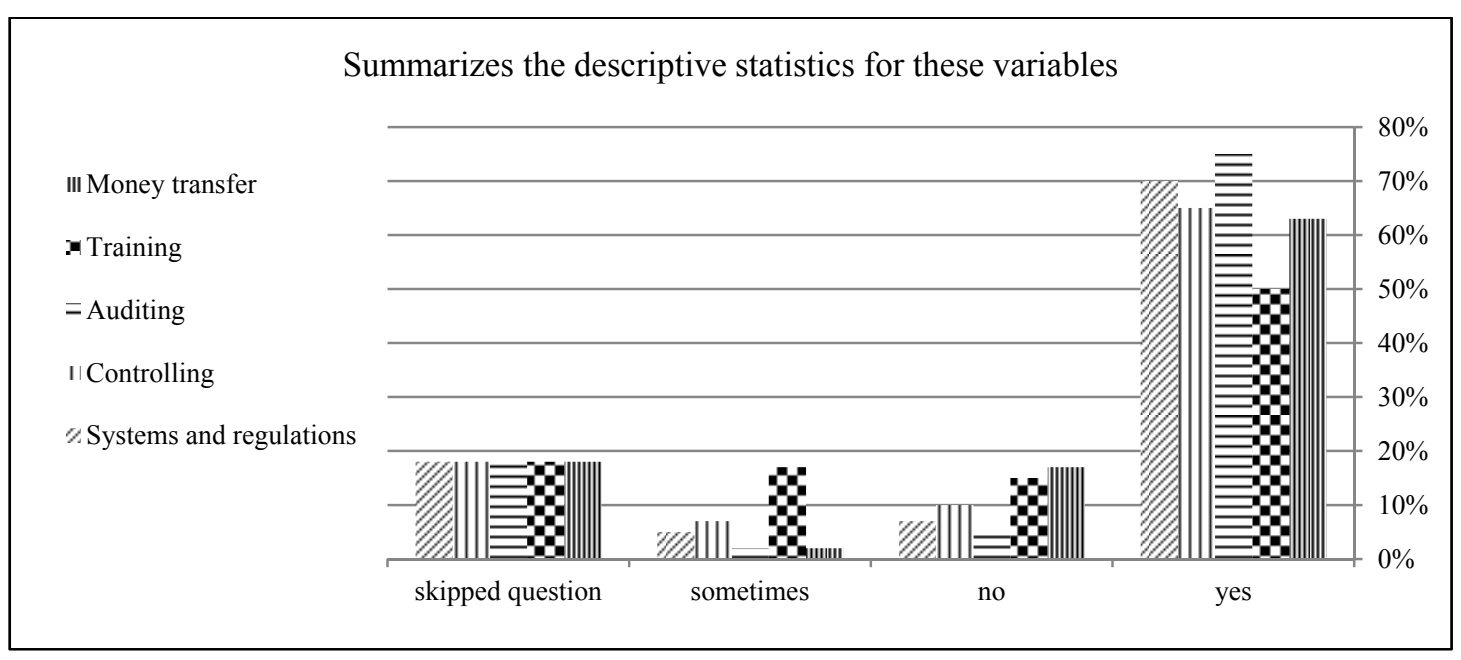

Figure 4. Summarizes the descriptive statistics for these variables

It is clear from table No. 8 that the weighted average of ratios for people who answered that the Anti-Money Laundering (AML) which included (Systems and regulations $S Y R G$, Controlling $C O N$, Auditing $A U D$, Training $T R$ and Transfer TRA) effect on investment funding about $65 \%$, and the weighted average of ratios who answered that the Anti-Money Laundering (AML) not effect on investment funding about $11 \%$ And the weighted average of ratios who answered that the Anti-Money Laundering (AML) sometimes effect on investment about $7 \%$, and the last of who skipped question about $18 \%$.

So, we can notice that the results regarding the impact of Anti-Money Laundering (AML) on investment funding is a significant relationship between Anti-Money Laundering (AML). and investment funding (INVF).

\section{Results and Solutions}

In light of analyzing the data and testing the hypotheses, the following results have been reached:

The impact of money laundering (ML) on investment funding is a significant and negative relationship between ML .and investments funding (INVF).

Also, there is a significant and positive relationship between AML (Systems and regulations, Controlling, Auditing, Training and money transfer) and investment funding (INVF).

To reduce the impact of Money laundering which represents a financial crime that might have negative affect on the stability of the economy, and investment funding, the researcher suggests many solutions:

\subsection{Solutions Regarding the Laws and Regulations}

It is required to put on more efforts into fighting money laundering like the issuance of laws and regulations in order to reduce money laundering, despite the presence of many laws and regulations which was issued by the Organization for Security and Co-operation in Europe (OSCE) when adopting the new OSCE Strategy Document for the Economic and Environmental Dimension at the Maastricht Ministerial Council in December 2003, and the issuance of laws and regulations from the United Nations Office on Drugs and Crime (UNODC) 2009 and 2010. Also, there are many stepped up efforts to combat money laundering from the Central bank of Jordan, these efforts are represented in the issuance of laws and regulations regarding Anti Money Laundering and Counter Terrorist Financing Instructions. Most important of these laws are:

The law No. (51/2010): this law includes:

1) Issued pursuant to the provisions of article $(99 / \mathrm{b})$ of the Banking;

2) Law No. (28) of 2000 and to the provisions of article (14/a/4) of the Anti Money; Laundering and Counter Terrorist Financing Law No. (46) 2007 In force.

\subsection{Solutions Regarding with Controlling}

It includes:

a) Customer due diligence (CDD);

b) Suspicious activity monitoring (SAM); 
c) Know your customer (KYC);

d) D-Case management and watch-list filtering.

\subsection{Solutions Regarding with Auditing}

The solutions regarding auditing includes the check from the falling items: the beginning of opening account ,the accepting money on deposit, when the bank gives the loans, when the bank issues a debit card, when the bank issues travelers' checks and when the bank Send and receive instructions on electronic funds transfers.

\subsection{Solutions Regarding Training}

It is required to step up efforts to fight money laundering by training the employees of banking and financial institutions.

\subsection{Solutions Regarding with Transfers}

It is required to step up efforts to fight money laundering issuance of laws and regulations regarding the exchange rate and transfers .There are many stepped up efforts to fight money laundering from the Central bank of Jordan, these efforts are represented in the issuance of laws and regulations regarding Anti Money Laundering and Counter Terrorist Financing Instructions. Most important of these laws are:

Regulation Anti Money Laundering and Counter Terrorism Financing Regulation related to Money Exchange Companies no. (2/2010) issued pursuant to the provisions of clause 4, paragraph (A) of article 14 of the applicable anti money laundering Act no. (46) For the year 2007.

\section{References}

Ayodeji, A., \& Mahmood, B. (2012). The impact of money laundering on economic and financial stability and on political development in developing countries: The case of Nigeria. Journal of Money Laundering Control, 15(4), 442-457. http://dx.doi.org/10.1108/13685201211266024

Balata, \& Khababa. (2006). Funding policies and their impact on the economies and institutions: A case study of Algeria and developing countries. Working paper, Mohamed Khider University of Biskra, Faculty of Economics \& Administrative Sciences, Algeria.

Brigitte, U., Melissa, S., Joras, F., Wouter, D. K., Madalina, B., \& Kristen, W. (2006). The amount and the effects ML. Report for the Austrian Ministry of Finance, 1-20.

Brent, L. B. (2002). The negative effects of money laundering on economic development, international economics group dewey ballantine LLP. Retrieved from http://www.afp.gov.au/ /media/afp/pdf/m/money-laundering-02.ashx

Conyers, D., \& Pearman. (2013). Impact of new bermuda anti-money laundering regime on investment fund operators and managers. Retrieved from http://www.conyersdill.com/publicationfiles/

Financial Action Task Force ( FATF). (2009). FATF/OECD. Retrieved from http://www.fatf-gafi.org

Iqra, I., \& Amir, R. (2012). Money Laundering-A Negative Impact on Economy. Global Journals Inc. (USA). Retrieved from http://journalofbusiness.org/index.php/GJMBR/article/view/814/741

Helen, S. F., Sebastian, B., Ledia, M. (2003). Money laundering: The case of Albania, Council of Europe. Retrieved from http://www.core-hamburg.de/documents/yearbook/english/04/Fink_Baumeister_Muco.pdf

Idowu, A. (2012). Anti-money laundering policy and its effects on bank performance on Nigeria Dept. of Management and Accounting Faculty of Management Sciences. Retrieved from http://www.saycocorporativo.com/saycoUK/BIJ/journal/Vol5No2/Article_19.pdf

Jack Law Group, PC. (2013). Anti-money laundering regulations on the horizine for investment adviser, curities and corporation counsel.

Kpmg.com, Global Anti-Money Laundering Survey. (2011). Retrieved from http://www.kpmg.com/Global/en/IssuesAndInsights/ArticlesPublications/Documents/anti-money-launderin gv2.pdf

Maria, E., De Boyriea, S., Pakb, J., \& John, S. Z. (2005). The impact of Switzerland's money laundering law on capital flows through abnormal pricing in international trade. Applied Financial Economics. Retrieved from http://www.tandf.co.uk/journals

Mark, E. S. (2012). R. T. P. J. Management Research (4th ed.). London: SAGE Publications Ltd. 
Quirk, P. J. (1996). Macroeconomic implications of money laundering. International Monetary Fund Working Paper 96/66. June. Retrieved from http://www.imf.org/external/pubs/cat/doctext.cfm?docno=WPIEA0661996

Quirk, P. J. (1997). Money laundering: muddying the macro economy, finance and development. International Monetary Fund, 34(1). Retrieved from http://www.imf.org/external/pubs/ft/fandd/1997/03/pdf/quirk.pdf

Swisher, Z. (2011). Applying the results and conclusion of the research process. Kimberly: S.N.

Tanzi, V. (1996). Money laundering and the international system. International Monetary Fund Working Paper. Retrieved from http://www.imf.org/external/pubs/cat/longres.cfm?sk=2029.0

United Nations Office on Drugs and Crime (UNODC). (2009; 2010). Retrieved from https://twitter.com/WorldCompliance

Note

Note 1. Significant at the 0.05 level.

\section{Copyrights}

Copyright for this article is retained by the author(s), with first publication rights granted to the journal.

This is an open-access article distributed under the terms and conditions of the Creative Commons Attribution license (http://creativecommons.org/licenses/by/3.0/). 